\section{Medical tourism}

\section{To the Editor:}

The distinguished Stephen Bezruchka, MD, brings up interesting issues in his recent editorial, ${ }^{1}$ some of which require response. At the outset, he is reminded that a number of the readers of Wilderness \& Environmental Medicine - myself included - have joined the organization which gave it birth not because we are trekkers, but for the experience in international and wilderness travel a missionary to the developing world requires. In this context, his choice of words to describe the effort - medical tourism - carries a connotation that borders on offensive. Dressing a leper's wounds or feeding children with kwashiorkor is hardly equivalent to standing in awe before the venerated Eiffel Tower, or Everest, for that matter. True, one has to get some personal satisfaction, but the motivation to be a missionary is different than the motivation to conquer Everest or visit Paris. It requires a desire to serve fellow humans. Additionally, the statement that missionary work is self-serving is nothing short of an accusation of hypocrisy and is frankly offensive.

Bezruchka asks the question, "Can it be justified"? The response to that question cannot be found-and must not be sought - among the plethora of public health vital statistics. Short-term medical care to a few hundred people in a country like Haiti, which has a population of several million, makes no impact in that country's health care crisis. Also, statistics sanitize the oppressive reality of poverty and all its consequences and distance us from our own responsibility in the perpetuation of this poverty. In any case, health care statistics for the developing world are difficult to find.

Missionary work, contrary to Bezruchka's tenet, can be resoundingly justified once the focus is away from statistical analyses. I have been involved for several years in missionary efforts in Haiti. Our team never intended to make an impact on the prevalence, say, of hypertension in that country. But the impact on some people's lives has been dramatic_-saving the life of a little girl with meningitis, the sight of a young boy who had a foreign object embedded in his cornea, rehabilitation of major injuries. To these people, our trips have been well worth the effort. That impact, however, will never be reflected in any health care statistic. Too many of us have forgotten that our basic responsibility is to people, not institutions.

Bezruchka's comments about the half-hearted contribution the United States makes to foreign aid are certainly true, but in no way exonerate us as individuals. Americans' voracious appetite for the consumption of this planet's resources has a major impact on the poverty of the developing world, whether we travel there or not. A sincere concern about poverty and disease in the developing world, however, requires us gets our hands dirty. Medicins Sans Frontieres, which Bezruchka implies is motivated by glamour, has rightfully earned the recognition it deserves by refusing to just sit by and watch. More of us should emulate them.

Bezruchka has argued elsewhere ${ }^{2}$ that treatment by itinerant doctors discourages referral to other facilities. This argument assumes that there is a facility that the patient can be referred to. In countries like Haiti, where more than $45 \%$ of the population simply has no access to health care, ${ }^{3}$ this argument is hollow. In our trips to Haiti, there were many who had never been exposed to any health care professional.

I do agree with Bezruchka that in order to be effective, one should learn as much as possible about the intended destination. Learning the language and the customs goes a long way toward effectiveness and generating good will. This is true, however, regardless of whether one is a missionary or a trekker. The traveler ignores this advice at his or her own peril.

Missionary work certainly presents many challenges: insufficient time and supplies, the logistics of medical waste disposal, etc. There are also inherent disadvantages to providing care for a short period of time, or for a limited number of diseases, or to a limited number of people. However, these are just convenient rationalizations to do nothing for the people but climb their mountains, run their rapids, or explore their caves. It is this very attitude that engenders so much ill will against Americans abroad. Missionary work may not be perfect, or for everyone, but many of us believe it's the only way to act when one refuses to sit by and do nothing to alleviate-however slightly - the plight of our brethren. That alone is sufficient justification.

Gerónimo Lluberas, MD

Marietta, GA, USA

\section{References}

1. Bezruchka S. Medical tourism as medical harm to the third world: why? for whom? Wilderness Environ Med. 2000;11: 77-78.

2. Bezruchka S. Medical treatment of local people by travelers. J Wilderness Med. 1992;3:1-3.

3. Haitian Ministry of Public Health and Population. Health Situation Analysis: Haiti 1996. Pan American Health Organization; 1996. 